\title{
The Problems in Professional Competence of Teachers in Teaching English Subject at Vocational High Schools
}

\author{
Syamsinar \\ hinarishine@gmail.com \\ STIE Tri Dharma Nusantara Makassar \\ Baso Jabu \\ basojabu@yahoo.com \\ State University of Makassar, Indonesia
}

\begin{abstract}
This research was intended to investigate the problems in professional competence faced by the English teachers of vocational high schools in Gowa, South Sulawesi, Indonesia. This research applied descriptive qualitative method. The data were collected by using three instruments: questionnaire, interview and observation checklist. The participants were two experienced English teachers, two inexperienced English teachers, and eight students. The professional competence indicators are adapted from the Regulation of the Minister of National Education of the Republic of Indonesia No. 16/2007. The results of this research reveal that the teachers' problems dealing with professional competence in teaching English at vocational high schools include (a) problem in mastering the materials, (b) problems in mastering the curriculum, (c) problem in developing materials creatively, (d) difficulties in developing the teacher professionalism continuously, (e) problems in using the information technology and (f) problems of classroom management.
\end{abstract}

Keywords: professional competence, experienced English teachers, inexperienced English teacher.

\section{INTRODUCTION}

Teachers are the direct actors of their own professional development (Gonzáles et al., 2002). The professional teachers must have academic qualification and competencies. The competencies that a teacher must have namely pedagogical competence, personal competence, social competence and professional competence, the Regulation of the Minister of National 
Education of the Republic of Indonesia No. 16/2007. Those competencies are integrated with teacher performance. As an ideal teacher, she or he must have a good qualification, professional and master the four teacher's competence.

However, Gultom in Antar News (2013) reported that the result of competency examination indicated that the teachers' quality in Indonesia was still low. The average score of the teacher competence test on July 1st, 2012 was 47.84 while the passing grade was 65. In addition, Suharini (2009) found that the Geography teachers' professional and pedagogical competence of the school which had A accreditation had good criteria. Whereas, the school which had B accreditation was still in low criteria.

Then the researchers would like to figure out the English teachers' competence of vocational high school. Therefore, they conducted a research for preliminary data about the problems of the English teachers dealing with the teacher competencies at vocational high schools in Gowa region at SMKN 1 Somba Opu and SMKN 2 Somba Opu. The result indicated that the teachers faced problems in pedagogical competence, personal competence, social competence, and professional competence. In pedagogical competence, they faced problems mostly in facilitating the development of the students' potentials. The students' potentials, in this case, are preparing various learning activities and communicating and understanding the effective and polite communication strategies. In social competence, they faced problems in conducting various programs to develop and improve the education quality and communicating with the teachers' community. In personal competence, the teacher faced problems related to the teacher role as a model for the students and society. In professional competence, generally the teachers faced problems in developing materials, communicating the materials and discourse aspects. Based on the result of preliminary data, the major problems faced by the English teachers at SMKN 1 Somba Opu and SMKN 2 Somba Opu were professional competence. However, Professional competence is one of the important competencies which must be improved and mastered by the English teacher of vocational high school especially toward mastering the subject matter of language aspects. Being successful in teaching process depends on the teachers' ability in developing materials creatively. The role of the teacher's professional competence is considered the most related to the teacher's performance.

Therefore, based on the data, studying the importance of professional competence for English teacher is essential in this research. The researchers focused on seeking the teachers' problems dealing with professional competence in teaching English. 


\section{LITERATURE REVIEW}

\section{Teaching Competency}

Professional teachers must have competence. Mulyasa (2007) stated that competence is knowledge, skills, and abilities or capabilities that a person achieves, which become part of his or her being to the extent he or she can satisfactorily perform particular cognitive, affective, and psychomotor behaviours. So, the competence is knowledge, skills and behavior that enable someone to do something well. In addition, Slavík (2008) defined the teacher competence as a set of knowledge, skills and teachers personal qualities. The teaching competency is associated with the complex combination of knowledge, skills, and abilities to have professional performance in the classroom as an educator.

\section{Professional Competence}

Professional competence is the ability in mastering the materials to fulfill the standard base competency which has been set by the Minister of Education. The teachers must have a number of standard competencies to be professional teacher either based on the Regulation of the Minister of National Education of the Republic of Indonesia No. 16/2007, Slavík (2008) or Bantang (2008). The following is the sub-competences of professional competence based on The Regulation of National Education Minister of the Republic of Indonesia.

a) Mastering the materials, the structure and the concept of the subject taught

b) Mastering standard competency and basic competencies of the subject taught

c) Developing the learning materials creatively

d) Developing their own professionalism

e) Using the information technology

Slavík (2008) categorized the teacher's professional competence into five items, they are as follows;

a) Mastery a systematic body of knowledge.

b) Ability to apply practical experience in the specialization according to the subject of the study.

c) Ability to transform the knowledge based on the subject of study.

d) Ability to integrate the inter-disciplinary knowledge and create subjectlinks.

e) Ability to use the information and communication technology effectively 
The other opinion came from Bantang (2008) who stated that there are some abilities that have to be owned by the teachers related to the professional competence. The abilities are:

- Mastering the subject taught

- Planning the lesson

- Managing the class

- Being able to use instructional media

- Understanding the students' characteristics

- Being able to select the appropriate materials

- Being able to conduct an action research

The categories of the three sources about professional competencies are related one another. Nevertheless, if we compare the sub-competence of these three sources, the categorization by The Regulation of National Education Minister of Republic of Indonesia No. 16/2007 is more developed than Slavík's work (2008) and Bantang's work (2008). Therefore, the researchers used The Regulation of the National Education Minister of the Republic of Indonesia No. 16/2007 as the main indicator in this research which covers the professional competence both suggested by Slavík (2008) and Bantang (2008).

The Professional Competence of Vocational English Teacher

The first point of the sub-competence that is mastering the materials, the structure and the concept of the subject taught differs for each teacher. The Regulation of the National Education Minister of the Republic of Indonesia No. 16/2007 specified the professional sub-competence for English teacher in particular they are as follows;

a. The teacher must have knowledge about language aspects in English (linguistic, discourse, sociolinguistic and strategies).

b. Mastering the English both written and oral forms, receptive and productive skills in communicative aspects (linguistic, discourse, sociolinguistic and strategy).

Mizne (1999) defined the linguistic competence is the ability of the teacher to use correct grammar, pronunciation, and vocabulary in a language. Discourse competence is concerned with the cohesion and coherence of utterances/sentences. Sociolinguistic competence is the ability of the teacher to produce utterances appropriate to the social situation in which they are spoken. And Strategic competence is how well the person uses both verbal 
forms and non-verbal communication to compensate for lacking of knowledge in the other three competencies.

The English teachers at vocational high school

It is suggested that the English teachers of vocational high school be required to have positive attitude toward English for specific purpose, knowledge of fundamental principle of the subject area (Hutchinson \& Waters in Kaimuddin, 1999). The teachers also have to consider the specific needs of the learners that give information related to the special terms. Nevertheless, Kaimuddin (1999) stated that many English teachers at Engineering realized that there are many special terms should be given but they did not have access for this.

Arnold (1998) in Wello and Nur (1999) mentioned three ways to improve the ESP teachers' knowledge of the content. First, the teachers can read books and articles on the area written for accountants. Second, develop the numbers of technical terms and define into simpler English. Third, they can also consult with other specialists teachers in the school. So, in improving the ESP knowledge, the Englishteachers of vocational high school must have the effort to find out more references and technical terms.

\section{METHOD OF THE RESEARCH}

The aim of this research was to describe the teachers' problems in teaching English in various departments at vocational high schools. This research was conducted by using descriptive qualitative method (Gay et al., 2006). The sampling technique used was purposive sampling technique. The researchers focused on state vocational high schools in Somba Opu district. There were two vocational high schools in this district. They were Sekolah Menengah Kejuruan Negeri 1 Somba Opu and Sekolah Menengah Kejuruan Negeri 2 Somba Opu. The researchers took the experienced teachers and inexperienced teachers of each school. So, the total number of teachers was four. Questionnaires were used for preliminary data to identify whether or not the teacher faced problems related to the teachers' competence. Interview and observation were the instruments used to collect the data about the teachers' problems in professional competence. The researchers used the semi-structured interview. They used observation checklist to fit the data that the participants described during the interview. To check the strength of the data, they used data triangulation. This triangulation involved several students at SMK Negeri 1 Somba Opu and SMK Negeri 2 Somba Opu. They used a semi-structured interview to gain data from the students. 
They employed the data analysis steps based on Miles and Huberman's model in Emzir (2012:129-136). The data were analyzed through data reduction, data display, and conclusion.

\section{FINDINGS}

The findings of the research are summarized in terms of the problems of the English teachers in professional competence in teaching English at vocational high schools in Gowa. The following is the data obtained from interview and observation from the participants.

a. Lack of vocabulary of special terms for various departments

Three of the four English teachers faced problems in mastering the vocabulary dealing with special terms of various departments.

Interview with teacher 1

"The problem is because the school has nine departments, automatically there are a lot of vocabularies which should be suited with the department we taught. The most difficult is Equipment either noun or verb."

Interview with teacher 2

"Usually there is vocabulary which is asked by the students and we do not know how to answer because it is too specific."

Interview with teacher 3

"There are many vocabularies that I do not know includes noun and verb".

The schools consist of eight and nine departments. The tools or terms which related to their study are different while teacher 1 , teacher 2 and teacher 3 were not familiar with all the terms or vocabulary used for several departments. The difficult words which the teachers found were nouns and verbs in Equipment and Design Department. During the observation, they never gave the technical terms related to the students' department in constructing the sentences. The students of teacher 1, teacher 2 and teacher 3 revealed that they had not been given the terms related to their department.

b. Lack of pronunciation

According to the interview data, only one teacher found a problem in pronunciation. This case was faced by teacher 3 as presented below. 
Syamsinar, Jabu: The Problems in Professional Competence ... $\mid 101$

Interview with teacher 3

"The problem is only a little, for example; there were words which difficult for me to distinguish such as the distinguish of Three: tiga with tree: pohon. If theoretically I can but maybe I am lacking of pronunciation."

There were certain words that she taught were difficult to differentiate in terms of pronunciation especially the words which have similar sounds.

c. Difficult to communicate the lesson by using English

Teacher 1 had a problem in applying the strategic competence in communicating the materials to make the students understand. The following statement presents her problem.

Interview with teacher 1

"The problem is when communicating the materials; the problem is sometimes if I communicate the materials in English, the students do not understand."

Interview with teacher 3

"The problem is if we used English sometimes the students do not understand, so we explain in the Indonesian language. Sometimes I have also a problem if I communicate in English is not very fluently."

Teacher 1 stated that if she used English in teaching the students did not understand. Based on the observation in Craft class, teacher 1 actively explained in English but the students tended to be passive and kept listen. Meanwhile, teacher 3 realized that she was not very fluent in communicating the lesson by using English. Due to these problems, she used Indonesian to transfer the knowledge. This is in line with the observation data, during the observation she taught by using the Indonesian language in teaching. It was confirmed by her students that she used Indonesian language and occasionally in English.

d. Difficult to achieve the basic competence and learning objectives

Based on the interview data, there was one of the teachers found difficulty to reach the target of learning objectives, as she stated in the following interview. 
Interview with teacher 1

"If basic competence is a reference for indicators which will be achieved in the learning process, yes actually there is a little problem. This is because of the time allocation in explaining the material is too short. Moreover, we have to reach many learning objectives targets which have been set in the syllabus."

The new regulation of curriculum 2013 which consists of four basic competencies and many targets of learning objectives must be achieved in one semester while teacher 1 had not comprehended the implementation of this curriculum.

\section{e. Lack of teaching planning}

The teachers must be well planned before teaching. Based on research findings, there was one of four teachers who did not have a lesson plan during the observation. The following is her statement.

Interview with teacher 1

"I have made lesson plan, but it was the previous lesson plan in a long time ago."

Teacher 1 owned a lesson plan in the previous semester but this semester she borrows the experienced teacher's lesson plan if she faces difficulty. Then, she taught the materials based on the module instruction without the lesson plan. Based on the observation data, she did not bring the lesson plan.

\section{f. Difficult to select appropriate materials}

The teacher must be able to select appropriate materials in teaching at vocational high schools. In interview data, two of four participants faced difficulties in selecting appropriate materials. They were teacher 1 and teacher 2 .

Interview with teacher 1

"This school consists of nine departments, to select the materials are rather difficult. The obstacle is in applying the material for students, the materials which are presented for students are not wholly specific to their department. These materials are not appropriate." 
Interview with teacher 2

"The problems are, there are several materials which are not familiar with several departments. The second problem is I want to develop the materials, but I do not have many references."

Teacher 1 stated the materials which she taught sometimes did not appropriate with the students. Based on the observation data, she taught conditional sentence type 1, type 2 and type 3 at once. She taught the materials based on a module without evaluated the relevant materials with the students' needs and level. This was indicated that she did not consider the relevant materials with the students' level. The students stated in interview data that he knew the formulas of the three types, but he did not know how to differentiate the use of the three types. Whereas teacher 2 also realized that the material is not appropriate to be taught for the student, but she did not change it because of lacking of references. In interview data, her students revealed that the materials given never concerned to the department.

g. Difficult to adapt the materials to be relevant to students' department

There were two teachers faced difficulties to adapt and develop the learning materials to be relevant for the students in various departments. They were teacher 1 , and teacher 3 . The problem of teacher 1 in relation to adapting materials for various departments is presented in the following sentence.

Interview with teacher 1

"My English knowledge is more likely to English for general purpose. So, nine various departments, I teach the same materials."

Interview with teacher 3

"If the teachers want to adapt the material is based on our capacity. The material for each department must be different. But the material which I teach is almost the same for every department."

Based on the teacher 1 explanation, she taught the students from different departments by using the same materials and exercises. Her students also clarified that she taught general materials based on the textbook or LKS 
without linking to their departments. Based on the observation data, she never linking the students' department in constructing the sentences. This case is in line with teacher 3 . The data of teacher 3 described that she taught the students the same materials for all departments without made the materials relevance with the students' needs. Based on observation data indicated that she did not adapt or develop the materials with students' department. This case was also clarified by her students.

h. Difficult to update material from many sources

The teachers should develop the professionalism continuously from many aspects. In interview data, three teachers realized that they faced difficulty in updating material from many sources. The following is their statement.

Interview with teacher 1

"The obstacle is in updating the information or material sources are rather difficult and we have to find outside."

Interview with teacher 2

"Maybe the problem is we have to facilitate our own by using a modem. It means the budget, the private budget. If the school has wifi or the internet, the best thing we can do is browsing material more often. And we have a network with English teachers, we can improve it better."

Interview with teacher 3

They consider that internet media is a good media to update and learn the information from different sources. However, the school did not facilitate the teachers and the teachers do not make any effort. During the observation, they only used the material in a textbook without combining with other references or teaching aids.

i. Lack of teacher development activities

Another aspect to develop the professionalism continuously is by involving in every kind of development activities namely Teacher Gro"Sometimes I want to improve my professionalism but the problem is an inadequate facility."

up working, Teachers' Discussion Subject and so on.Teacher 1 believed that teachers' group working can influence the professionalism. Nevertheless, she 
also never attended the forum. In addition even teacher 2 and teacher 3 did not attend the teachers group working activities. It can be seen by their explanation in the following statement.

Interview with teacher 2

"I have not heard yet."

Interview with teacher 3

"Oh... I do not know, I think there is not."

The data showed that teachers of a vocational high school in Gowa region especially in SombaOpu district were still a lack of teacher development activities.

j. Not using information and communication technology for effective communication

The use of media in teaching and learning process makes the teaching and learning activities becomes more interesting and effective. Nevertheless, the teachers in the school did not maximize the utilizing of information and communication technology. Based on research findings, the teachers did not use the information and communication effectively. It can be proved by data of teachers' interview and observation. Even the teachers had been facilitated with LCD, teacher 2 and teacher 3 were rarely to use it in the teaching process. This was also clarified by the students' of teacher 2 in an interview. They stated that they had been teaching about two semesters by those teachers, but the teachers never used LCD in the classroom.

Meanwhile, during the observation in another school found that teacher 4 did not use the language laboratory in teaching. This information was also gained by his students of grade X and grade XI. They uttered that they had not been taught in the language laboratory. By this case, the benefit of media did not apply maximally by the teachers in teaching.

\section{k. Lack of classroom management}

The professional teacher is demanded to be able to have good management. The good management can be seen by the capability of the teacher in managing the time, materials and classroom. This challenge is also faced by the teacher 1 in the classroom. In findings, the students of teacher 1 informed that she was lacking in managing the students in the class especially when she explained the materials. They stated that some of their friends in the 
class were still noise when she explained the materials. The researchers also found that she let the students operate their handphone during the learning process.

\section{DISCUSSION}

Based on the result of the research indicated that there were eleven problems in professional competence faced by the teachers in teaching English subject at vocational high schools in Somba Opu sub-district. The teachers of vocational high schools were still lack of vocabulary used for various departments, this case is in accordance with Kaimuddin (1999). In addition the teachers also dominantly used the Indonesian language in spite of English in communicating the materials, Rodriguez (2012). Dealing with the teaching device, the inexperienced teacher still faced problem to achieve basic competence, this case is in line with Padmadewi (2007). In other side, she taught the materials based on the module instruction without having the lesson plan (Syamsuri, 2010). In delivering the materials, the inexperienced teachers faced difficulties to select appropriate materials. Sometimes, even they realized that the materials are not appropriate to be taught for the students but they did not change it (Ghufron, 2012). In addition, an inexperienced teacher and an experienced teacher did not develop the materials to be linked to the students' department activities or tools. This case is accordance with Tomlinson (2003). Thus, it is important for teachers to be involved in the Teachers' Discussion Subject to discuss their obstacles in the class especially dealing with the materials. In fact, three of four teachers never involve in the teacher group working activities. In terms of the utilizing media in teaching three teachers still did not utilize the information and communication technology maximally. This problem is accordance with Liuzhi (2012) found that most teachers in vocational colleges are still adopting the mode of language-based "textbook+ blackboard". These problems are the aspects of professional competence of the Regulation of National Education Minister and Culture of Republic of Indonesia No. 16/2007, Slavik (2008) and Bantang (2008).

On the other side, there was one of the inexperienced teachers who was low of classroom management, Ayuni (2013). This problem is the part of professional competence based on Bantang (2008).

\section{CONCLUSION}

In English teachers' competence especially in linguistic aspect, the major problem faced by the teachers is dealing with lack of the vocabulary of special terms. On the other hand, the minor problem in linguistic aspect is in pronunciation aspect.Communicative competence is considered to be the 
medium problem of English teachers' professional competence, because of the four participants, two participants faced difficulty in communicating the lesson. In addition, the major problems faced by the teachers in developing the teacher professionalism continuously and not using information and communication for effective communication.

Based on the findings, the researchers concluded that the professional competence of English teacher at SMKN 1 Somba Opu and SMKN 2 Somba Opu were still low. The teacher who had the lowest professional competence was inexperienced teacher from SMKN 2 Somba Opu. The teacher who had the highest professional competence is the experienced English teacher of SMKN 2 Somba Opu, who is certified. He had also attended educational training, educational training of technical terms, Teachers' Discussion Subject and involved in action research competition.

Nevertheless, among the group of an experienced teacher, it was found that an experienced teacher of English who comes from another discipline is not the same with the real experienced teacher of English in terms the professional competence. This is due to the low linguistic aspect. Because she had attended Educational TrainingsTeacher and Teaching Professional Training Program, she is good at teaching planning and materials selection.

\section{SUGGESTION}

To be a professional teacher, the teacher should have the professional competence, such as based on The Regulation of National Education Ministry of Republic of Indonesia No. 16/2007, Slavík (2008) or Bantang (2008). The English teachers of SMKN 1 Somba Opu and SMKN 2 Somba Opu still need to improve their professional competence especially the English teacher professional competence in linguistic aspect.

In addition, the researchers suggested that the government facilitate the vocational high school teachers with education training of ESP knowledge. Henceforth, the government and the certificate organizer must be consistent in terms of teachers' academic qualifications. 
108| ELT Worldwide Vol. 2 No. 2 October 2015

\section{REFERENCES}

Ayuni. (2013). Pengelolaan Kelas Dalam Pembelajaran. Retreived at August 7th 2014 from http://www.cademia.edu//Makalah Pengelolaan Kelas_Dalam_Pembelajaran

Bantang, S. (2008). Guru Sebagai Pendidik Yang Humanis. Makassar: Pustaka Refleksi

Gay, L.R., et al. (2006). Educational Research. Pearson: Merrill Prentice Hall.

Gonzáles, A., Montoya, C., Sierra, N. (2002). What do EFL Teachers Seek in Professional Development Programs? Voices of Teachers.ÍkalaRevistade language cultural. Retrieved from http://aprendeenlinea.udea.edu.co/revistas/index.php/ikala/article/

Ghufron, S. (2012). Problematika Pembelajaran Aspek Kebahasaan di Sekolah dan Solusinya.Universitas Darul Ulum Lamongan.

Huaxiao Z. (2012). Discussion about Vocational English Teaching Reform. International Conference on Education Technology and Management Engineering: Lecture Notes in Information Technology, Vols.16-17. Retrieved at December 5, 2013 from http://www.iier.org.au/iier15/breen.html.

Kaimuddin. (1999). Need Analysis of Technical English for Technical High School Students. Dissertation. Makassar: Postgraduate Program Hasanuddin University.

Mulyasa. (2007). Standar Kompetensi dan Sertifikasi Guru. Bandung: Remaja Rosdakarya.

Peraturan Menteri Pendidikan Nasional Republik Indonesia Nomor 16 Tahun (2007). Standar Kualifikasi Akademik dan Kompetensi Guru. Jakarta: Menteri Pendidikan Nasional

Suharini. (2009). Studi Tentang Kompetensi Pedagogik Dan Profesional Bagi Guru Geografi Di Sma Negeri Kabupaten Pati. Retreived at August7th2014fromhttp://journal.unnes.ac.id/nju/index.php/JG/article /view/99 
Syamsinar, Jabu: The Problems in Professional Competence ...|109

Suwito, Erlin. 2012. Problematika Pengembangan Kompetensi Professional Guru PAI di MTs PGRI Selur. Referred Academic Journal.iiste.org. Retrieved at July 10th 2014 from www.scribd.com/doc/158163037-problematika-pengembangankompetensi-professional-guru-PAI-di-MTs-PGRI-Selur.

. Wello, M. \& Nur, H. (1999). An Introduction to ESP (English for Spesific Purpose).Published: BadanPenerbitUniversitasNegeri Makassar. 